FIDES QUAERENS PULCHRUM:

\title{
PRACTICAL THEOLOGICAL PERSPECTIVES ON THE DESIRE FOR BEAUTY
}

\author{
Johan Cilliers \\ Department of Practical Theology and Missiology \\ Stellenbosch University
}

\begin{abstract}
In this article, the notion of 'desire' is critically interpreted in terms of the classic theological notion of 'quaerens' (as for instance in: fides quaerens intellectum; faith in search of understanding). 'Quaerens' indicates the quest for (or paradox of) something that is not yet attained, although already experienced, here understood as a quest for beautyfides quaerens pulchrum. The concept of beauty is multi-layered, but traditionally it is viewed in a romanticized sense, as something (or an experience) that is fine, excellent, noble and honourable. In this article this romanticized view is critiqued within an aesthetical understanding of practical theology, in which beauty is understood as the quest for a radically different (and paradoxical) form of proportion within the experience of pain, horror and destruction. In this sense beauty is not contradicted by the notion of ugliness, but rather indicates the quest for the healing of proportions and the connection between the visual and transcendent meaning. The article takes a brief look at the development of some paradigmatic shifts in practical theological methodology, before discussing possible aesthetical practical theological meanings of beauty.
\end{abstract}

Key Words: Beauty, Aesthetics, Practical Theology, Desire, Faith

\section{Life is Beautiful}

La vita è bella - life is beautiful

This was the title of the widely acclaimed Italian film, produced in 1997 by film director Roberto Benigni (who also played the leading role, as well as co-writing the script), in which an Italian Jew, Guido Orefice, is taken away to a Nazi concentration camp together with his son, Giosué, and his wife, Dora. ${ }^{1}$ In the camp Guido makes use of his fertile imagination to hide his son away from the Nazi guards and to convince him that the whole experience is nothing other than a competition, a game of sorts, in which you have to accumulate 1000 points in order to win the grand prize, namely a real tank. Guido's performance-in-imagination is so passionate that he convinces his son, up to the very end, that the guards are mean only because they want to win the tank, and that all the other children in the camp are hiding away because they also desperately want to win the game. ${ }^{2}$

\footnotetext{
At the $71^{\text {st }}$ Academy Awards (1998) the film won the awards for Best Actor, Best Original Dramatic Score and Best Foreign Language Film.

2 In one of the most hilarious but deeply profound scenes in the film, a burly German soldier bursts into the barracks and starts to bark orders. First he enquires whether someone can speak German - in order to translate his orders to the gathered group of Jews. Guido volunteers, although he does not understand a word of German. So the scene is set: on the one side the vicious-looking guard, spewing chilling realities about the
} 
The film depicts a remarkable understanding of what beauty entails - remarkable because it dares to speak of, and enact, beauty within a context of utter destruction and unspeakable inhumanity. It not only illustrates the power of observation - the way in which Guido sees the bleak surroundings - but also the power of imagination, i.e. the way in which he interprets these surroundings and re-imagines them in such a way that he vicariously anticipates a new and alternative reality for his son, namely that of play. In effect he transforms the concentration camp into a playground. Ridiculous, one could say. But exactly herein - in the absurd paradox (read: scandal) of Guido's re-imaginations - lies the beauty of this beauty.

In this article I take a closer look at (this specific understanding of) beauty. From the outset it should be said that the notion of beauty is complex, multi-layered and in flux. In his book On Beauty, Umberto Eco for instance traces the historical development of the notion of beauty from the aesthetic ideal in ancient Greece to the developments during the Middle Ages, the Renaissance, through to the twentieth century and speaks of different faces of beauty during different epochs, for instance beauty as proportion and harmony, as ugliness (monsters!), as magic, as reason, as the sublime, as romantic ideal, as provocation, and as consumption, etc. ${ }^{3}$ The list seems to be never-ending.

\section{Aesthetics: a Sense of Beauty}

Historically speaking, the notion of beauty has always been associated with that of aesthetics. ${ }^{4}$ The term 'aesthetics' - originally coined by Alexander Gottlieb Baumgarten in 1735 - was soon broadened to include the aspect of beauty, since people experience their world - for example, nature - on a pre-logical level not as a number of quantities, but as satisfying, or beautiful. This experience is also at the root of the experience of music, art and poetry. Hence aesthetics was soon linked to the concept of beauty and also the

camp, and on the other, Guido - translating for the sake of his son, who must remain convinced that this is only a game. Parts of the dialogue go like this:

Guard: Listen carefully; I will say this only once. Guido: The game starts now. Whoever is here is here; whoever is not is not. Guard: You were brought to this camp...Guido: The first one to get 1000 points wins. The prize is a tank! Guard: ... to work! Guido: Lucky him! Guard: Any effort to sabotage the work will be punished by death. The execution will take place in the courtyard with a shot in the back (the guard points towards the courtyard, then his back).Guido: The names of those in the lead will be announced over the loudspeakers at the courtyard, and the one with the least points has to wear a sign saying 'jackass' right here on his back (Guido points towards the courtyard, then his back). Guard: Three things you should not forget: one, do not try to escape; two, follow all orders without question; three, all efforts to resist will be punishable by death. Is that clear? Guido: You'll lose your points for three things: one, if you cry; two, if you want to see your mommy; three, if you're hungry and want a snack. Forget about it!

And so it goes. In the end Guido even makes the brutal guard part of the game - saying in his 'translation' that this guard lost 40 points himself because he ate a jam sandwich yesterday (an apricot one, although he would have preferred strawberry!), and that the guards eat all the lollipops themselves (so don't even bother asking for one), and that the guard apologizes for leaving so soon, but he is busy playing hide and seek, and he has to go before the others find him!

3 Umberto Eco, On Beauty. London: Secker \& Warburg, 2004:37-430.

4 There seems to have also been diverse viewpoints on the notion of aesthetics for centuries. The term 'aesthetics' was, however, used for the first time by the German philosopher Alexander Gottlieb Baumgarten in his Reflections on Poetry (1735) and Aesthetica (1750). He wished to found a new science and to distinguish it from both the logical sciences (formal rules and norms for thinking) and the natural sciences he wanted it to be a science that could research sensory experience in a disciplined manner. For this science of sensory knowledge Baumgarten used the Greek term aesthesis (observation) and the associated noun aesthetika (indicating the observed objects) as focal points. Cf. the discussion by Renate Reschke, Schön/Schönheit, Ästhetische Grundbegriffe 5. Stuttgart, Weimar: JB Metzler, 2010:398f. 
(beautiful) arts. The result was that art (or the theory of art) gradually began to define aesthetics. By the end of the eighteenth century Romantic philosophy considered aesthetics as the philosophy of the art work. Kant understood aesthetics as the theory of beauty, as judgment in taste, and then also as subjective judgment. ${ }^{5}$

Although 'beauty' still had a place in these definitions of aesthetics, the primary understanding of aesthetics was that of philosophical theorizing about art. Beauty was merely understood as part of the definition of aesthetics in as far as scholars still wanted to see beauty as a component of art itself. In the twentieth century, however, beauty as the foundational concept of aesthetics became more marginalized and was ultimately practically removed from the definition of aesthetics, because the term 'beauty' increasingly no longer had a place in the way that people understood art itself. While aesthetics - and beauty - is a multidimensional concept which at least includes dimensions such as judgment, aesthetic observation and imagination (anticipation and transformation), today the concept has in most cases become attenuated. ${ }^{6}$

The key concept of aesthetics, namely beauty itself, is clearly battling for survival. Not only is it threatened by certain elements of post-modernism, but also by a hermeneutical heritage which propagates a division between ethics and aesthetics, religion and art, and religion and pleasure. Add to this the marginalization of the concept of beauty in the iconoclasm, asceticism and legalism of some Christian traditions and clearly the concept cries out for renewed attention and development. Although it has always been part (in some forms) of the Christian tradition - in its architecture, liturgy, iconography, etc. - it was also to some extent considered as peripheral. In many churches beauty simply degenerated into kitsch; and art became plastified expressions of a consumerist society.

Many view 'beauty' through a haze of romanticism. For them, beauty is all about objects (or experiences) that are, fine, excellent, noble and honourable. Beauty is seen as

5 The contribution of Kant (1704-1784) to the aesthetics debate cannot be overrated. He consolidated the thoughts of his time masterfully and laid the foundation for further thinking on aesthetics. For him most aesthetic judgements were merely reports of pleasure or pain - judgments of the senses. Some of these judgments also expressed an appreciation of beauty - so judgments of taste or opinion. As opposed to the empiricists, Kant retained the distance and distinction between aesthetical pleasure and sensory experience by distinguishing between sensory experiences (Empfindung) and feeling (Gefühl). The first is an objective version of the senses, while the last is inherently subjective. If you, for instance, look at a green landscape, you experience the beauty through your senses, but feel aesthetic pleasure. The determining foundation of judgments or taste can thus not be other than subjective - sharply different from cognitive judgments, although there may be formal similarities. Aesthetic judgments do not claim to be knowledge; they are neutral, because they deal with pleasure as pleasure. They function in another sphere to that of knowledge or morality. Yet aesthetic pleasure is not arbitrary, as it shows universal features in the sense that it functions with the (common human) abilities of imagination and understanding. During aesthetic experiences these abilities have free play, which leads to a feeling of pleasure and thus an experience of beauty. Kant evaluated the aesthetical as a type of opposite of the rational. And yet he and other classic authors such as Schiller and Baumgarten did not deny the importance of aesthetics for our search for truth, knowledge and meaning (for an extended discussion of the importance of Kant for our understanding of aesthetics, cf. JS Begbie, Voicing Creation's Praise. Towards a Theology of the Arts. New York: Continuum T and T Clark, 2003:187-191; JR Betz, Beyond the Sublime: The Aesthetics of the Analogy of Being (Part One). Modern Theology 21/3 July 2005:376f; P Orth, Ästhetischer Religionsunterricht. Katechetische Blätter. Zeitschrift für Religionsunterricht, Gemeindekatechese, Kirchliche Jugendarbeit. 128/4, 2003:250.

6 Cf. E Farley, Faith and Beauty. A Theological Aesthetic (Aldershot, Burlington USA, Singapore, Sydney: Ashgate, 2001), x; also S Van Erp, Fides quaerens imaginem. Esthetica als fundamentele theologie: geloof op zoek naar beelden. Tijdschrift voor Theologie 43, 2003:17-18.

7 Cf. Cilliers, J, 2010, 'The unveiling of life: Liturgy and the lure of kitsch', HTS Teologiese Studies/Theological Studies 66(2), Art \#815, 5 pages. DOI: 10.4102/hts.v66i2. 815. 
"the pretty, the merely decorative, or the inoffensively pleasant", 8 its intention being nothing more than merely evoking a sentimental feeling about pretty sunsets and artistic flower arrangements. Others interpret beauty exclusively in terms of corporeal and even hedonistic and narcissistic trends: beauty then becomes a slogan for 'lifestyle' advertisements and cosmetic make-overs. Beauty becomes nothing more than "a naked woman advertising perfume." The classic connection between beauty, goodness, and truth, has been fully shattered. ${ }^{10}$

Many people regard beauty as an illusion, or even worse, a lie. Surely the world and our existence on this planet are often anything but 'beautiful'. Can a snow-capped mountain, pointing its peaks through white clouds, for instance, be 'beautiful' - if the slaughtering of innocent women and children by marauding soldiers takes place at its foot? Were the colourful flowers on the Cambodian 'killing fields' really 'beautiful'? Or the 'beautiful' music brought forth from the Jewish violins playing Bach in the concentration camps to help sooth Nazi officers? No, "Truth is a lie; morality stinks; beauty is shit.",11

For many, 'beauty' can simply not, or no longer, be trusted. ${ }^{12}$ Brown for instance refers to the negative attitude of some against the very notion of aesthetics, an attitude that stereotypes those who busy themselves with "such 'trivial' things as taste and aesthetics."13 People who spend time on aesthetics and beauty are considered to be dismissive of the really important matters, as evaders of the poor and marginalized whom Jesus loved so much. ${ }^{14}$ In fact many people consider aesthetics as a sort of luxury, pursued and enjoyed by

8 DB Hart, The Beauty of the Infinite. The Aesthetics of Christian Truth. Grand Rapids, Michigan: Eerdmans, 2003:15.

9 Terry Eagleton, The Ideology of the Aesthetic. Oxford: Oxford University Press, 1990:372.

10 Classical thinkers such as Augustine and Aquinas categorised beauty alongside goodness and truth as being part and parcel of God's revelation to us, as a perfect unity of beauty, goodness and truth. Cf. C Pastro, 2005. Kunst in de katholieke kerk vóór en na het Tweede Vaticaans Concilie. Wereld en Zending. Tijdschrift voor interculturele theologie. 1, 2005:56. Indeed, these three dimensions of God's revelation “....can never be separated. It is questionable whether we can ever know one except in intimate connection with the others.... There is a truth - a reality, an authenticity - about beauty and goodness. There is goodness - a wholesomeness, salutariness, sacredness - about both beauty and truth. There is beauty in truth - in its selfevidence, its simplicity, its transparency - and in goodness, especially in the comeliness of moral character.' P Avis, God and the Creative Imagination. Metaphor, Symbol and Myth in Religion and Theology. London and New York: Routledge, 1999:78-79.

11 Eagleton, The Ideology of the Aesthetic, 372.

12 According to John Dillenberger there are at least three possible approaches to the relationship between aesthetics and theology. The first maintains the complete division between these disciplines - as, for example, advocated by Rudolf Bultmann and Karl Barth. The latter expressed his admiration for someone like Mozart in public and hung a reproduction of Grünewald's crucifixion scene (on the Isenheimer altar) in his study- so that he could regularly look at the portrayal of John the Baptist pointing towards Christ and meditate on it. Ironically, however, he strongly opposed the installation of stained glass windows in the church in Basil. His judgment about images and symbols in the church was unambiguous: "They have no place at all in a building designed for Protestant Worship". Dillenberger mentions a second more moderate relationship between art and religion, as pleaded for by George Lindbeck and Paul Tillich, an approach in which artworks (at least on occasion) can be perceived as depictions of religion itself, for some perhaps even as moments of revelation. Thirdly, Dillenberg indicates an approach in which art can function as (a) model for theology, as for example in the case of Hans Urs von Balthasar and Karl Rahner. Dillenberger himself pleads for an approach in which critical dialogue can take place, a dialogue in which both these disciplines retain their unique identity and method, but mutual enrichment occurs without a seamless overlapping, devoid of any space for criticism. J Dillenberger, A Theology of Artistic Sensibilities. The visual arts and the church. New York: Crossroad, 1986:217f.

13 B Brown, Good taste, Bad taste, and Christian Taste. Aesthetics in Religious life. Oxford: Oxford University Press, 2000:3.

14 Brown, Good taste, Bad taste, and Christian Taste, 3. 
the elite, while there are more urgent matters that the church ought to be paying attention to such as population issues, HIV and AIDS, poverty, and global terror - which has nothing to do with 'beauty'. ${ }^{15}$ Indeed, at first glance aesthetics does not seem to be at the core of our religion. ${ }^{16}$ Jesus did not drive people out of the temple because the interior decoration was not up to standard, and he did not - as far as we know - teach his disciples to sing harmoniously.

So, why bother with beauty? And: what do we in fact mean by beauty?

\section{The Beautiful Chaos of Being}

We take our cue from a change in paradigm during the $19^{\text {th }}$ century. During this era, the 'other side of beauty' was rediscovered, inter alia by people such as Arnold Ruge, Friedrich Vischer and Karl Rosenkranz. ${ }^{17}$ Rosenkranz spoke about the Ästhetik des Hässlichen (aesthetics of ugliness), and called ugliness Negativschönen (negative beauty but still beauty). ${ }^{18}$ According to him, “Ästhetiker haben nicht das Recht, Erfahrungen der Wirklichkeit allein mit erträglichen Stichworten vom Edlen, Reinen un Schönen zu reflektieren." ${ }^{\prime 19}$ No, beauty should rather be understood as a space where all the disorders, the imperfections, even the evils and the one-sidedness of our experiences of reality do not necessarily estrange us from the truth, but where we rather have the possibility of stumbling upon 'truth'.

The ontological function of (ugly) beauty is therefore not so much to narrow the chasm between ideal and reality, but to contrast this chasm by means of a paradox that opens up a radically different perspective on the same reality. ${ }^{20}$ In this sense, 'beauty' not only lies on the borders between so-called order (proportion) and so-called chaos (disproportion), but also indicates a fundamentally different understanding of order and proportion. Beauty is simultaneously the order of change and the change of order, and as such it is fragile, fleeting, endangered and contingent. ${ }^{21}$ According to Rainer Maria Rilke beauty is nothing more than a terrible beginning (Schrecklichen Anfang) to unthought of possibilities. ${ }^{22}$

Within this paradigm, chaos is not viewed as the negative of order; it is not non-order. The Greeks already understood chaos as the possibility for order, as space and horizon filled with potential (Möglichkeitshorizont). ${ }^{23}$ Nietzsche spoke about the beautiful chaos of being (schöne Chaos des Daseins). ${ }^{24}$ In this sense, beauty could be interpreted as the

15 Cf. Begbie, Voicing Creation's Praise, xvi.

16 On the other hand: the meaning of religion has been traced back to the linguistic roots of ligature, which basically means a tying together of significances. In both culture (which includes aesthetics) and religion we find various attempts to do exactly this. Cf. DJ Louw, Cura Vitae. Illness and the healing of life in Pastoral Care and Counselling. Wellington: Lux Verbi. BM, 2008:49.

17 Cf. the discussion by Renate Reschke, Schön/Schönheit, Ästhetische Grundbegriffe 5. Stuttgart, Weimar: JB Metzler, 2010:416f.

18 Karl Rosenkranz, Ästhetik des Hässlichen (1853.) Leipzig: D Kliche, 1996:5.

19 Rosenkranz, Ästhetik des Hässlichen, 9.

20 Reschke, Schön/Schönheit, 429.

21 Reschke, Schön/Schönheit, 434.

22 Rainer Maria Rilke, Duineser Elegien, in: Rilke, Werke in drei Bänden, hg. H Nalewski, Bd. 1. Leipzig: D Kliche, 1978:579.

23 Bianca Theisen, Chaos-Ordnung, Ästhetische Grundbegriffe 1. Stuttgart, Weimar: JB Metzler, 2010:754.

24 Friedrich Nietzsche, Die fröhliche Wissenschaft (1882), in: Nietzsche (KGA), Abt. 5, Bd. 2, 1973:201. 
dialectic or paradox, i.e. as the perpetual and reciprocal movement between chaos and order, a movement which also indicates and creates its own 'order'.

These developments underlined the fact that, in a sense, 'beauty' does not exist in itself, but always within the realm of paradox: out of the experiences of suffering and threat, i.e. chaotic disproportionateness, emerges the quest for beauty as healing of proportions. Broadly speaking, one could say that the 'meaning' of beauty can only be understood in terms of the interaction (paradoxical tension) between the object itself (for instance in the proportions of the object); the perception of the one who views the object (beauty being "in the eye of the beholder"); and in the 'alternative reality' to which the object points and which it anticipates. Even Baumgarten, the founder of aesthetics as sensorial science, expressed his belief that 'beauty' does not simply exist, but is rather the result of a creative event - created inter alia through the way in which the object is perceived: "Schönheit ist weder objective Dingeigenschaft noch subjektiver Empfindungsinhalt, sondern gelungene Erkenntnis im Bereich des Sensitiven und gelungene Kreativität, auf die Welt oder die Kunst gerichtet." ${ }^{25}$

This relationship between the proportion of order and the disproportion of chaos, and the resultant anticipation of a radically different 'proportion of order' is important for our understanding of beauty. Disproportion of chaos is not the deformity of proportionate order. Chaos is something in itself - as is order. The paradox between these two realities could be described as beauty. Beauty exists in the tentative space between proportionate order and disproportionate chaos, anticipating a new, fundamentally different type of order. The quest for beauty is sparked off by this paradoxical tension; it is perpetually energised by the movement from disproportion to proportion, i.e. from chaos to order. Understood in this sense, beauty therefore does not exclude the ugly (or: disproportionate), but in fact incorporates it in its quest for (healing of) proportion. The very existence of the paradoxical tension created by disproportion kindles a faith that is in search of beauty (fides quaerens pulchrum).

This is indeed particularly true of faith and theological aesthetics. The beauty of God is often revealed exactly under circumstances of chaotic disproportionateness, which could be viewed as disturbing ugliness. But it could also be viewed as 'a beautiful representation of ugliness. ${ }^{26}$ Umberto Eco concludes: "The forms of Greek Beauty cannot be used to portray the flagellation of Christ, crowned with thorns, dragging the cross to the appointed place of torment, crucified and dying amid the torments of a long and martyred agony." ${ }^{27}$ Romanticised notions of harmonious proportion cannot be used to describe the cross. The cross can only be understood as 'beauty' within the paradoxical and tentative space and tension between chaos and order. Only in theological sense - or: through faith (fides) - can 'ugly' be observed as 'beautiful', or as chaos that is en route to a healed, i.e. radically different form of proportion. As a matter of fact, the ugliness of the cross is the strange 'beauty' of God, par excellence, because this ugliness lives within the tension and paradox of cross and resurrection. ${ }^{28}$

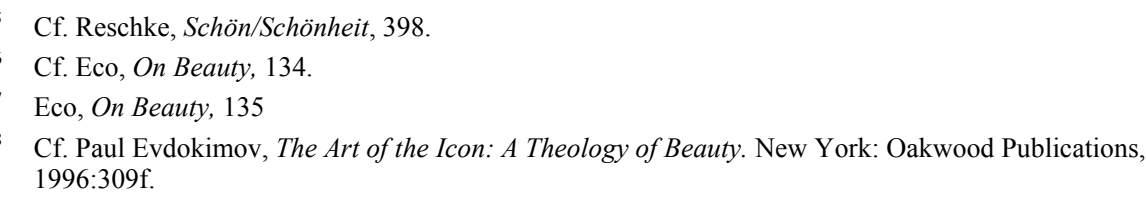




\section{The Beauty of Ugliness}

It is clear: not all beauty is desirable, at least not in the normal sense of the word. Beauty, understood theologically, rather resides in the desire for the non-desirable. A case in point would be the following depiction:

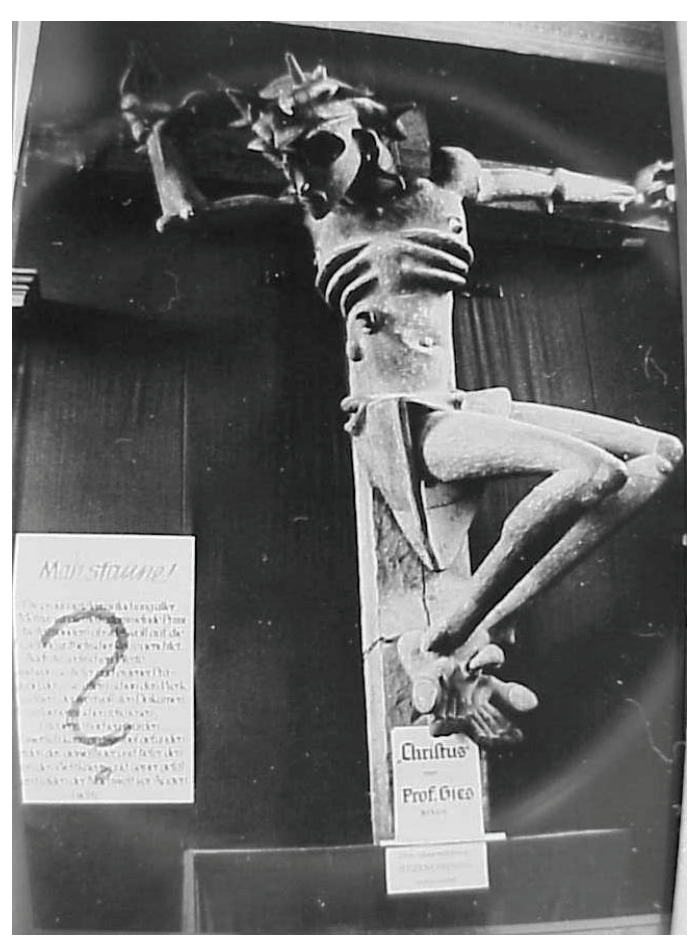

Is this picture 'beautiful', or not? Well, yes, and no. The artist is Ludwig Gies, and the artwork - a sculpture - is called Kruzifixus (1921). This artwork belongs to a collection of art called entartete Kunst (degenerate art) ${ }^{29}$ - an aesthetical phenomenon that dramatically illustrates the different, and in this case diametrically opposed ways, in which 'beauty' could be interpreted. During the era of Nazi Nationalsozialismus all forms of art that did not express 'beauty' according to the interpretation of the regime, were seen as 'degenerate', and actually ridiculed. ${ }^{30}$ In the now (in)famous exhibition that was held in Munich (1937) 'degenerate' expressionistic art works depicting faces were actually placed next to photographs of faces of people suffering from mental illnesses, institutionalized in mental asylums. The intention was clear: 'degenerate' art was to be labeled as madness (Wahnsinn) and incompetence (Nichtkönnen). ${ }^{31}$

Many of the art works were 'interpreted' by means of mocking slogans placed in strategic places throughout the exhibition. The Kruzifixus of Gies was actually placed at the entrance to the first room, which was filled with religious art, inter alia that of Emil Nolde, Max Beckmann, and other eminent artists of the time. The slogan here contained the phrase “...freche Verhöhnung des Gotterlebnis", which means something like: (these art works express the) disrespectful mockery of the experience of God. ${ }^{32}$ The (double) irony in this cannot be missed: The Nazi regime calling this depiction of the cross, which, in an

29 It is obviously impossible to do justice to this rich phenomenon within the art world within the confines of an article like this. For an in-depth discussion, cf. Peter-Klaus Schuster (hrsg.), Die 'Kunststad' München 1937. Nationalsozialismus und 'Entartete Kunst'. München: Prestel-Verlag, 1998; Also Wolfgang Klein, Dekadent/Dekadenz, Ästhetische Grundbefriffe 1. Stuttgart, Weimar: JB Metzler, 2010:30f.

30 The irony is that the Nazi regime intended to display over 600 'degenerate' art works only for a limited period of time (four months) as part of their indoctrination programme - to illustrate to the German people what art is not and should not be - but in the end the intended period was extended to four years, the exhibition making a tour of almost the whole of Germany, because it was so popular that thousands kept on flocking to view this particular form of art!

31 Cf. Klein, Dekadent/Dekadenz, 30.

32 Cf. Schuster, Die 'Kunststad' München, 122. The complete slogan read: 'Unter der Herrschaft des Zentrumsfreche Verhöhnung des Gotterlebnis". 
unmistakable manner, expresses the un-respectful mockery that Jesus did in fact experience on the cross, un-respectful mockery of our experiences of God! ${ }^{33}$

According to the ideology of Nationalsozialismus, ideal beauty to the contrary hinged on classical understandings of proportion and even naturalism. ${ }^{34}$ Art had to be beautifully proportionate, as in (their understanding of) nature. Chaos - disproportionateness - was unacceptable. All forms of art that did not express these characteristics, moreover in terms of Germanic worldviews, were rejected, and even destroyed.$^{35}$ Beauty had to be 'perfect' (Volkommen), had to express that which was timeless, or at least antique, and not contextual. As a matter of fact, the whole idea of art being contextual, i.e. linked to a specific time and culture, was seen as a Jewish invention. ${ }^{36}$ In short, the notions of aesthetics and degeneration were actually seen as synonymous. These sentiments could not be expressed in stronger terms than the following: "Der Begriff des Ästhetischen ist für uns mit der Vorstellung von etwas Angekränkeltem, Unmännlichem, Verweichlichtem verbunden. Man empfindet weithin das Wort ästhetisch als den denkbar schärfsten Gegensatz etwa zu kämpferisch, männlich, hart." ${ }^{37}$

At first glance, the artwork of Gies does in fact portray a Christ that is virtually stripped of his flesh and, actually, is awful to look at. But, as we have noted, there is also another way of looking at it, discerning a different form of beauty, a different form of 'proportion' - through the lens of a faith that is in search of beauty.

\section{Fides quaerens pulchrum: Faith in Search of Beauty}

In everyday parlance beauty is something to be desired. We desire beauty, because we like it, and wish to enjoy it. In this regard it is worthwhile to take note of the extended 'definition' of beauty offered by Umberto Eco:

'Beautiful' - together with 'graceful' and 'pretty', or 'sublime', 'marvellous', 'superb' and similar expressions - is an adjective that we often employ to indicate something that we like. In this sense that what is beautiful is the same as what is good, and in fact in various historical periods there was a close link between the Beautiful and the Good.

But if we judge on the basis of our everyday experience, we tend to define as good not only what we like, but also what we should like to have for ourselves... A good is that which stimulates our desire. ${ }^{38}$

Eco, however, goes further and distinguishes between desire and beauty:

33 Perhaps they unwittingly paraphrased a text from Isaiah, which speaks of another broken and undesirable figure $(53: 2,3)$ : "He had no beauty or majesty to attract us to him, nothing in his appearance that we should desire him. He was despised and rejected by men, a man of sorrows, and familiar with suffering. Like one from whom men hide their faces he was despised, and we esteemed him not."

34 Cf. Hilmar Frank, Bildende Kunst, Ästhetische Grundbegriffe 1. Stuttgart, Weimar: JB Metzler, 2010:679.

35 Another irony is that the Nazi regime soon discovered the monetary value of this art, and started to sell thousands of items (which was collected after the initial collection of 600 items), to the highest bidders, in order to help finance the war effort! Moreover: not only German art works were sold, but even classic works by people such as Vincent van Gogh and Oskar Kokoschka - which were also classified as degenerate art. These were seen as not being 'beautiful', and people such as Van Gogh were deemed to have no sense of 'proportion'!

36 Cf. Hilmar Frank, Bildende Kunst, Ästhetische Grundbefriffe 1. Stuttgart, Weimar: JB Metzler, 2010:679.

37 Hans Arnold, Voraussetzungen einer nationalsozialistischen Kunstkritik, in: Nationalsozialistische Monatshefte (1936), H. 78, 836.

38 Eco, On Beauty, 8-10. 
If we reflect upon the detached attitude that allows us to define as beautiful some good that does not arouse our desire, we realize that we talk of Beauty when we enjoy something for what it is, immaterial of whether we possess it or not... A beautiful thing is something that would make us happy if it were ours, but remains beautiful even if it belongs to someone else. Naturally we are not dealing with the attitude of those who, when they come across a beautiful thing such as a painting made by a great artist, desire to possess it out of a certain pride of enormous economic value. These forms of passion, jealousy, lust for possession, envy or greed have nothing to do with the sentiment of Beauty.

The thirsty person, who, having found a spring, rushes to drink, does not contemplate its Beauty. He or she may do so afterwards, once thirst has been slaked. This explains where the sense of Beauty differs from desire. ${ }^{39}$

Desire is not that easy to describe - as is the case with beauty. During the nineteenth century someone like Frans Hemsterhuis distinguished between the notions of pleasure and desire and stated that the latter formed the central concept through which every human being's life could be interpreted. Desire (désir) is the first sensation of being alive, as well as the last of the human soul that finds no pleasure in this world. Pleasure (jouissance) is experienced when that which is desired is attained, but it remains fleeting and intransient hence life is characterized by the never-ending search for the perfect pleasure (la jouissance parfaite $).{ }^{40}$ Indeed, desire can be linked to the yearning for future fulfillments - a longing that however never experiences the potential of pleasure in the present, "... einem Begehren, für das typisch sei, dass es begehrt, ohne von der Verwirklichkeitsmöglichkeit des ersehnten Genusses beeinflusst zu werden." 41 Desire seems to be characterized by perpetual restlessness, roaming 'from one object to another. ${ }^{42}$

Desire could of course be described in many other ways also, but is normally defined as something (or someone) that is sought after or yearned for, an object that is craved and even coveted, but never (fully) attained. ${ }^{43}$ Desire is almost always about a sensorial experience of beauty, and specifically beauty as proportion and harmony - it is indeed something that we like and would also like to have for ourselves. In terms of Eco's metaphor, nothing would be more 'beautiful' than a bubbling spring of water - for a person dying of thirst! But this thirst is never (fully) quenched, and this 'beauty' seems to be always out of reach.

Eco, however, also refers to a sense of beauty that differs fundamentally from desire. In our view, this sense of beauty could be described in practical-theological terms as faith that is in search of beauty (fides quaerens pulchrum). ${ }^{44}$ Quaerens - the search of faith - is about

39 Eco, On Beauty, 8-10.

40 Frans Hemsterhuis, Alexis, ou de l'âge d'or, in Hemsterhuis, (Oeuvres philosophiques), Bd. 2. Leeuwarden: LSP Meyboom, 1846:152.

41 Jochen Schulte-Sasse, Einbildungskraft/Imagination, Ästhetische Grundbegriffe 2. Stuttgart, Weimar: JB Metzler, 2010:103.

42 Thomas Hobbes, Leviathan, or The Matter, Forme \& Power of a Common-Wealth Ecclesiasticall and civill (1651.) New York/London: RE Flathman/D Johnston, 1997:55.

43 Jochen Schulte-Sasse, Einbildungskraft/Imagination, 103.

44 Practical theological methodology has undergone some fundamental paradigm shifts in the past decades, often described in terms of a search, or quest for, that which has not yet been attained, articulated in the classical Latin expression fides quaerens (faith in search of). Cf. Louw, Cura Vitae, 20, 74. Broadly speaking, the following distinctions indicate some of these shifts, namely practical theology as fides quaerens intellectum (faith in search of understanding); here the intention is to understand, interpret and proclaim the revelation of God in a logical and cognitive manner, especially within an ecclesiological context. The emphasis is on teaching. Intellectum should, however, not be understood here as the logical and positivistic stance of 
the creative tension between chaos and order, a tension that results in a radically new order; it is about the interpretation of, and therefore hermeneutical movement between chaos and order in anticipation of this new order; it is about the beautification of God in the midst of, or rather due to, ugliness. ${ }^{45}$ It is not necessarily something that we like or would like to have; it is more than a sensorial experience of beauty as proportion and harmony. The quest of quaerens indeed differs fundamentally from the craving of desire. This quaerens is about the desire that we in fact do not desire.

So, how could the practical-theological characteristics of this quest of quaerens be described? In my opinion, there are at least four keywords that are of importance here - the same keywords already referred to in connection with Benigni's Life is Beautiful. As a matter of fact, Benigni's film could well serve as a type of metaphor for a faith and practical theology in search of beauty. The first keyword has to do with the way in which we observe reality (observation); the second with the way in which we interpret this observation (imagination); the third with the way in which we view an alternative reality

traditional orthodoxy, but rather as the hermeneutics of paradox; as fides quaerens verbum (faith in search of words); This entails a narrative and non-directive approach, complemented by fitting modes of communication and discourse. The emphasis is on the act of expression and processes of verbalisation. It is about the creativity of articulation. The classic distinctions of Maurice Merleau-Ponty between primary and secondary modes of expression come to mind. He referred to spoken and speaking language (le langage parlé et le langage parlant). Spoken language is language that has become fixed in linguistic baggage and cultural heritage, while speaking language is language at the advent of a thought, at the moment where it makes itself an advent of sense. Cf. Maurice Merleau-Ponty, The Prose of the World, translated by John O'Neill (Evanston: Northwestern University Press, 1973:10; as fides quaerens actum (faith in search of acts); the emphasis is on stronger integration of theory and practice, liberation, transformation and on ways of doing practical theology. Cf. the title of Dingemans's book: GDJ Dingemans, Manieren Van Doen. Inleiding tot de studie van de Praktische Teologie. Kampen: Kok, 1996. The focus is primarily on praxis as a reflection on the intentionality within the act, and secondarily on the development of skills; as fides quaerens spem (faith in search of hope); here the emphasis lies on the understanding and experiencing of meaning as anticipation of the future, as well as the means to foster and facilitate this through the liturgy, pastoral care, preaching, etc. The significance of eschatology plays an important role in this regard, as the anticipation of the (advent of) the novum; and as fides quaerens visum (faith in search of concrete visualisation); this is linked to the notion of aesthetics as fides quaerens imaginem (faith in search of imagination). The intention is to aid people to discern traces of God's presence by means of visual and virtual realities. This is linked to the notion of perspective: how you 'see' reality - and the invisible - from the angle of spirituality. The role of modern technology (internet, mass media, etc.) is taken into consideration; as fides quaerens corporalitatem (faith in search of embodiment). This is a holistic approach, taking the embodiment of humans seriously, inter alia also as the address of revelation. Our bodies are central to what we perceive and experience, also in terms of our relationship with God. It is the prime locus of God's presence with us. This understanding of embodiment is of specific importance for practical theology, as it entails the notions of contextualisation, immediacy, encountering, embracement, communality, radicalisation and concreteness. I am of the opinion that the existentialia which are brought into play in the different modes of faith-seeking (intellect, language, acts, hope, visualisation, etc.) can only be understood within the paradigm of embodiment. Cf. JH Cilliers, Fides quaerens corporalitatem: perspectives on liturgical embodiment. Verbum et Ecclesia. 30 (1), 2009:50-64; as fides quaerens societatem (faith in search of social interrelatedness and interconnectedness). The concept of embodiment can easily be misunderstood in terms of an exclusive individualistic or even denominational and congregational meaning. It may even deteriorate into egocentrism and narcissism. Practical theology, however, is about embodiment, also, and primarily understood in its public form. It is about society. The basic, technical meaning of the Latin word societas is partnership, or association for trading purposes, but it can also denote any group with shared interests - a community or society with an implied union for a common purpose and not a mere assembly. Therefore: fides quaerens societatem, which is a bridge-crossing approach, taking practical theology out of its exclusive ecclesiological boundaries, striving to interact with a variety of communities (faith communities included) in order to serve and enrich, but also to be served and enriched by these communities in a collaborative and reciprocal way. Cf. JH Cilliers, Fides quaerens societatem: Praktiese Teologie op soek na sosiale vergestalting. Tydskrif vir Geesteswetenskappe.49 (4), 2009:624-638.

45 R Bohren, Dass Gott schön werde. Praktische Theologie als Theologische Asthetik. München: Kaiser, 1975:33. 
(anticipation); and the fourth with the way in which we live within, and embody, this reality (celebration).

According to Baumgarten aesthetics is basically about the science of sensory knowledge. ${ }^{46}$ It hinges on the art of observation. The quest for beauty, and consequently also the quest of a faith and practical theology that searches for beauty, cannot be understood or achieved without the science of sensory knowledge, i.e. aesthetics. ${ }^{47}$

A first and fundamental step in (aesthetical) practical theological methodology would therefore be to observe, not only that which is commonly seen as 'beautiful' in the sense of being 'desirable', but also that which at first glance could be described as 'ugly'. Perhaps we could say that aesthetical observation sees the beautiful in the beautiful, but also the ugly in the (commonly accepted as) beautiful, as well as the beautiful in the ugly. It has a keen sense for the Beauty of Ugliness, and in terms of the Kruzifixus depicted above, the ugly beauty of the crucified.

Practical theology that takes life (reality) seriously, should not 'sanitize' its observation of reality, or prematurely place it within softening or blurring theological categories. In this sense, aesthetical practical theology is not a sort of luxury, pursued and enjoyed by the elite, while there are more urgent matters that the church ought to be paying attention to, such as population issues, HIV and AIDS, poverty, and global terror - rather the eye that observes it all.

But this observation entails more than just 'seeing' reality, and taking note of empirical data. Aesthetics observation is about discernment, about an interpretation of sensory experiences. It is about observation through the lens of imaginative faith. The 'meaning' of the Kruzifixus depicted above can, for instance, not be found through empirical or phenomenological observation - for that it needs the aesthetical art of imaginative interpretation. As skandalon, the Kruzifixus is ugly. But through the lens of faith it becomes beautiful; through the lens of faith the ugliness of the cross is transformed into a different type of beauty. These emphases take us further than mere empirical observation; indeed, practical theology - also so-called empirical practical theology - is about more than just data. It is also about discernment, indeed about a faith (fides) that imaginatively interprets that which the eye sees.

Perhaps another difference between beauty and desire becomes apparent here. Normally desire is directed at objects that we observe, and instinctively yearn for. But desired objects are not necessarily interpreted - like in Eco's analogy of a person that suffers from thirst: the fountain is observed - and desired - but not interpreted. No one dying from thirst would ask questions such as: where does this fountain come from? What geographical circumstances made this possible? What would the quality of this water be, etc.? No, thirst - desire - sees, and consumes.

46 Cf. the discussion by Renate Reschke, Schön/Schönheit, 398f.

47 Numerous theologians and artists and theologian-artists have pointed out the fundamental correspondences between aesthetics and theology. This includes scholars such as Horst Schwebel, Friedhelm Mennekes, Günter Rombold, George Pattison, Doug Adams, John Dillenberger, Diane Apostolo-Cappadona, etc. For a good orientation to the topic, cf. GE Thiessen, Exploring a Locus Theologicus: Sacramental Presence in Modern Art and its Hermeneutical implications for Theology. In: The Presence of Transcendence, Eds Lieven Boeve \& John C Ries, Leuven: Peeters Press, 2001:213-222. There are indeed clear structural similarities between the methodologies of theology and the aesthetic (art), for example, in the process of observation, imagination (including interpretation and anticipation) and (re)construction. Cf. Van Erp, Fides quaerens imaginem, 16. 
Therefore desire is normally not directed at objects that we think we have no need for. Who in fact needs - and thus desires - an ugly monstrosity on the cross as depicted above? Indeed to understand the 'need' for this cross, one is dependent on interpretation, on imaginative discernment; one needs to look deeper than the surface. Consequently, a practical theology that 'desires' beauty needs to be more than an eye that observes it all; it should also be an imaginative spirit that contemplates what it sees - from the perspective of faith.

Practical theology has the task of observing, and of interpreting, but it does not end here. By means of imaginative interpretation, a better or another reality is anticipated. In this sense, fides quaerens pulchrum (faith in search of beauty) is yet another expression of fides quaerens spem (faith in search of hope). It entails the quest for meaning in the present, in the light of the ever in-breaking future. Anticipation flourishes in the space of adventus, i.e. the presence of the coming One. ${ }^{48}$ It is exactly within the tentative space of adventus (presence of the coming One) that chaotic disproportion gives birth to (the quest for) the healing of proportion. It is this tentative space of adventus that transforms desire into the quest of faith (fides quaerens). Desire is, by definition, the perpetual roaming from one object to another, without finding fulfillment in any one of these objects. But the space of adventus, i.e. the hopeful anticipation of the future, is also about participation, about a new state of being, about an alternative habitus.

An interesting analogy here would again be the concept entartete Kunst. It is interesting to note that the word entartet was not originally used in a negative sense, i.e. as degenerate. It simply intended to describe an art form - a form of beauty - that has taken on a totally new form (the keyword being art, the German word for being). Thus: art as expression of a new being. With this word the artists representing this particular art movement simply wished to express their intention to follow a totally different aesthetical route. Only later did the Nazi regime implement the concept within their propaganda programme in a negative sense. ${ }^{49}$ What the artists understood as 'new being', the regime called 'degeneration.' Once again, the irony cannot be missed: the regime stereotypes this form of art (new being) as degenerate, but in fact they were guilty of degeneration themselves - failing to observe, to imaginatively interpret and anticipate, and consequently to appreciate this particular expression of a new beginning. The regime felt safe in its iron-clad ideology, not open to renewal, rather grasping back to anachronistic understandings of 'beauty'.

On the contrary, an imaginative anticipation implies a new being, which speaks of a new ethos. ${ }^{50}$ Such an ethos celebrates beauty, even if it is amidst chaos; indeed it celebrates the 'beautiful chaos of being' (Nietzsche) ${ }^{51}$ It not only anticipates, but already participates in, and as such embodies the beauty of being. Imaginative anticipation becomes participatory anticipation. It is no longer subjected to iron rules that are intended to keep 'reality' intact (reality, in fact, is never intact), but rather celebrates the presence of a new, given reality - of the adventus.

It celebrates the fact that life is beautiful.

La vita è bella!

48 Cf. JH Cilliers, Time out. Perspectives on liturgical temporality. NGTT. 50 (1 en 2),2009:26-35. Cf. also JH Cilliers, Liturgy as space for interpretation. Practical theology in South Africa, (2011, forthcoming), 13.

49 Cf. Schuster, Die 'Kunststad' München, 104.

50 The latter presupposes a way of being that correlates with 'beauty', i.e. how you are as human being in a dignified manner. Already according to Plato, it is the love of knowledge that leads a person to good acts, because good acts are identical with the Truth and Beauty. Therefore acts are attracted to the Good precisely by means of aesthetics. Cf. Hart, The Beauty of the Infinite, 158.

51 Nietzsche, Die fröhliche Wissenschaft, 201. 